\title{
Treponema pallidum within cells of a primary chancre from a human female
}

\section{JOHN A. SYKES, JAMES N. MILLER*, AND ARNOLD J. KALAN}

From the Research Department, Southern California Cancer Center, the California Hospital Medical Center, and the Treponemal Research Laboratory ${ }^{\star}$, Department of Medical Microbiology and Immunology, U.C.L.A. School of Medicine, Los Angeles, California, U.S.A.

Electron microscope studies of ultrathin sections of material from human syphilitic lesions have been relatively few in number and appear to have been initiated by Drusin, Rouiller, and Chapman (1969) who studied biopsy material from a 2-week-old penile lesion occurring on the glans penis of a 22-year-old male. Hasegawa (1969) reported studies on papular

Received for publication June 18, 1973

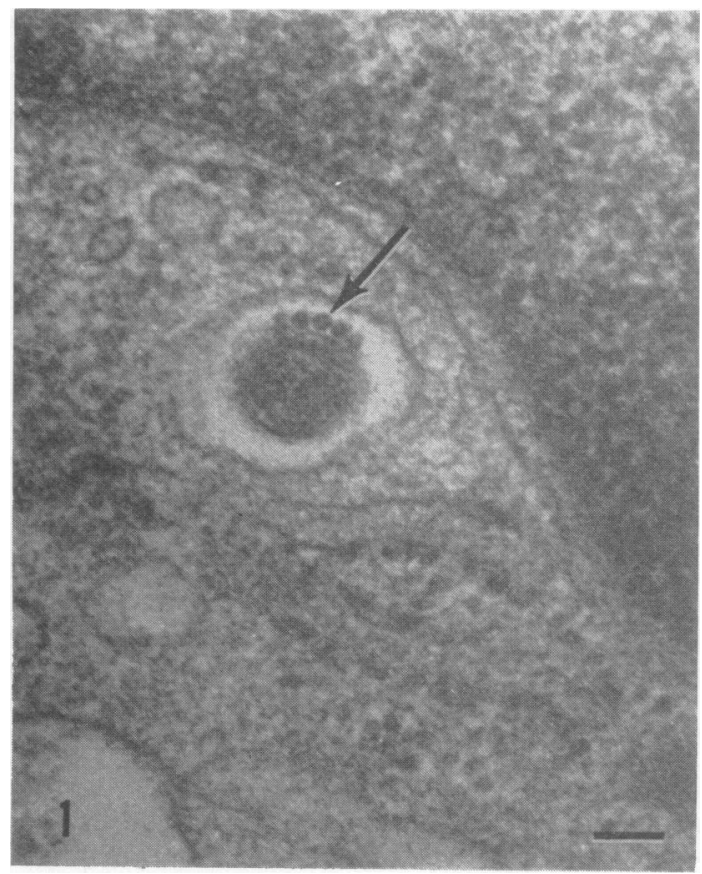

FIG. 1 Part of a fibroblast from human primary syphilitic lesion showing a cross-section of a typical T. pallidum in a vacuole within the cytoplasm. Five tubular axial filaments are clearly visible (arrow). Unless otherwise marked the bar in each illustration indicates $100 \mathrm{~nm} . \times 70,000$ lesions from the glans penis, the scrotum and around the anus taken from a 28-year-old male. Azar, Pham, and Kurban (1970) studied material from a penile lesion of 1 month's duration and more recently Weigand, Strobel, and Glassman (1972) examined material from a 3-week-old penile chancre. The present report concerns the findings obtained from examination of a lesion occurring in a human female.

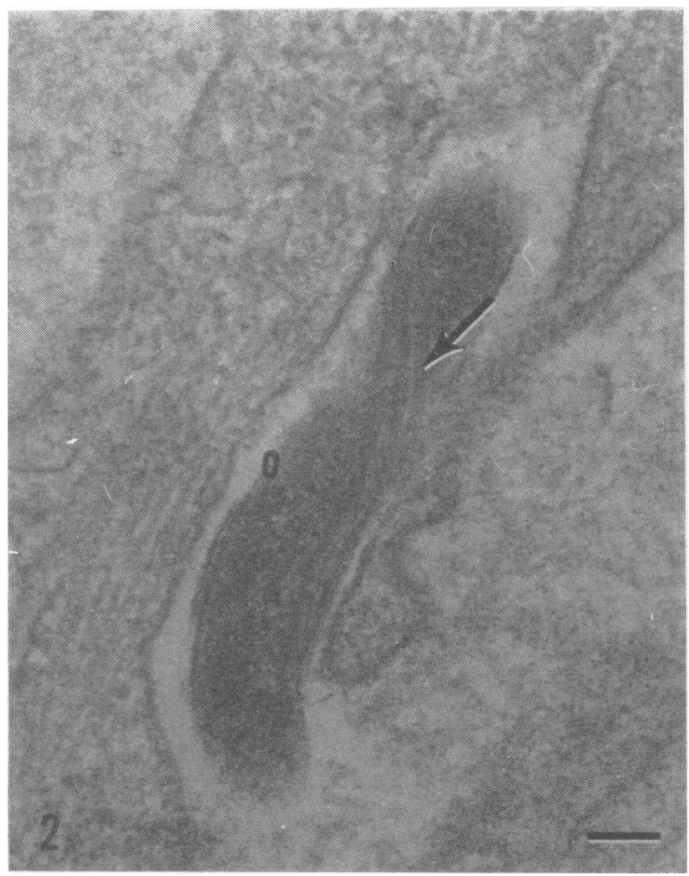

FIG. 2 A portion of a fibroblast showing a glancing longitudinal section of part of $a \mathrm{~T}$. pallidum entering (or leaving) the cell. Three axial filaments (arrow) are seen crossing the organism and part of the limiting membrane is shown at $0 . \times 70,000$ 


\section{Material and methods}

\section{TISSUE}

The biopsy specimen, which measured $4 \times 3 \times 3 \mathrm{~mm}$., was taken aseptically from a primary lesion of approximately 1 week's duration on the inner aspect of the right labium of a 23-year-old female. For transport to the laboratory, the tissue fragment was placed in a vial containing 3.6 per cent. glutaraldehyde in Millonig's buffer (Millonig, 1961).

\section{ELECTRON MICROSCOPY}

The tissue was washed with Millonig's buffer (three periods of $15 \mathrm{~min}$. each) before overnight post-fixation at $4^{\circ} \mathrm{C}$. with 1 per cent. $\mathrm{OsO}_{4}$ in the same buffer. The tissue fragments were again washed three times with the same buffer and then dehydrated by using a graded series of concentrations of ethyl alchol before final dehydration in propylene oxide. The double-fixed, dehydrated tissue fragments were flat embedded in Epon 812. Sections of 50 to $80 \mathrm{~nm}$. were cut with an LKB Ultrotome using a diamond knife (Du Pont), floated onto distilled water, and collected on 200-mesh copper screens coated with Formvar. Before examination in a Siemens Elmiskop IA, the sections were double-stained with uranyl nitrate and lead citrate.

\section{Results}

The appearance of the organisms was identical to that seen in rabbit testes infected with the pathogenic $T$. pallidum (Nichols). A typical cross-sectional view of a $T$. pallidum lying within a vacuole in a fibroblast can be seen in Fig. 1, and a portion of an organism cut longitudinally as it was entering or leaving a fibroblast is shown in Fig. 2. These organisms appear identical in appearance and dimensions to organisms of the pathogenic Nichols strain of $T$. pallidum seen in the rabbit testes as described by Sykes and Miller $(1971,1973)$ and Lauderdale and Goldman (1972).

The organisms present in this lesion from a human female have a diameter of $171 \mathrm{~nm}$. with axial filaments 24 to $27 \mathrm{~nm}$. diameter. As the material was received in 3.6 per cent. glutaraldehyde, it was not possible to extract the tissue to obtain other measurements, such as length, pitch, number of spirals, etc. The above measurements on less than twenty right cross-sections are within 4 per cent. of measurements for the Nichols strain of $T$. pallidum handled in the same fashion (Sykes and Miller, 1971, 1973). Fibroblasts were frequently seen to contain treponemes; part of an organism within the cytoplasm of such a fibroblast can be seen in Fig. 3 .

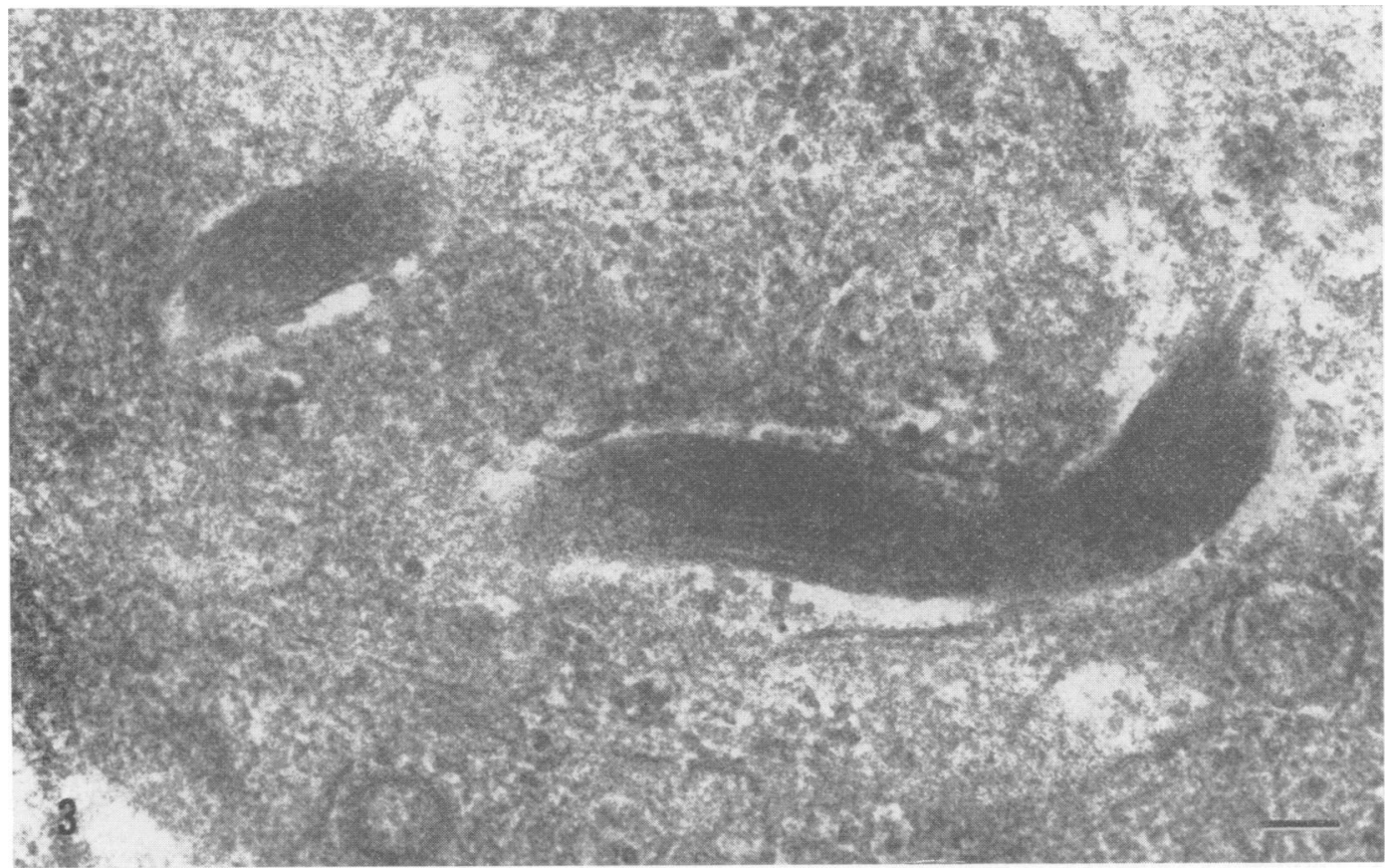

FIG. 3 Part of a fibroblast showing longitudinal cuts through portions of intracytoplasmic treponeme. 70,000 . 
Large numbers of organisms were present in the spaces between epithelial cells as well as within the cytoplasm of many of these cells (Fig. 4).

The most unexpected finding in this preliminary study of a human primary syphilitic lesion was the occasional presence of $T$. pallidum in the nucleus of some epithelial cells. The appearance of one intranuclear $T$. pallidum (Figs $5 a$ and $b$ ) suggested that some degeneration might have occurred, possibly as a result of the action of intracellular enzymes. The organism is cut in a glancing cross-section and shows four axial filaments which have an average diameter similar to that of the filaments seen in Fig 1.

It is of interest that, although $T$. pallidum was occasionally found in the cytoplasm of the endothelial cells of small capillaries, the organisms were never seen in the lumen; they were, however, frequently observed in the lymphatic channels associated with these small blood vessels.

\section{Discussion}

In a study of $T$. pallidum (Nichols) within infected rabbit testes, Sykes and Miller (1971) demonstrated that the organisms were present not only in plasma cells, but also in fibroblasts, interstitial, and Leydig cells and in spermatocytes. The present study of biopsy material from a primary lesion in a human female has confirmed the findings of Azar and others (1970), who described the presence of intracellular T. pallidum in neutrophils, macrophages, endothelial and perivascular connective tissue cells as well as within plasma cells. Our findings, however, were contrary to those of Hasegawa (1969) who failed to see organisms in the plasma cells of a condyloma latum lesion, but found them in the ground substance of the dermis.

The present study, therefore, has extended the findings of Azar and others (1970) but differs from those of Drusin and others (1969) and of Hasegawa (1969). Treponemes were found within lymphatic channels, but never in capillaries and were also seen in the cytoplasm of endothelial cells, epithelial cells, fibroblasts, plasma cells, and macrophages. Typical $T$. pallida were also seen within the nuclear substance of two epithelial cells.

The findings of intracellular treponemes in human tissue cells lends emphasis to the suggestion of Sykes and Miller (1971) that intracellular organisms might

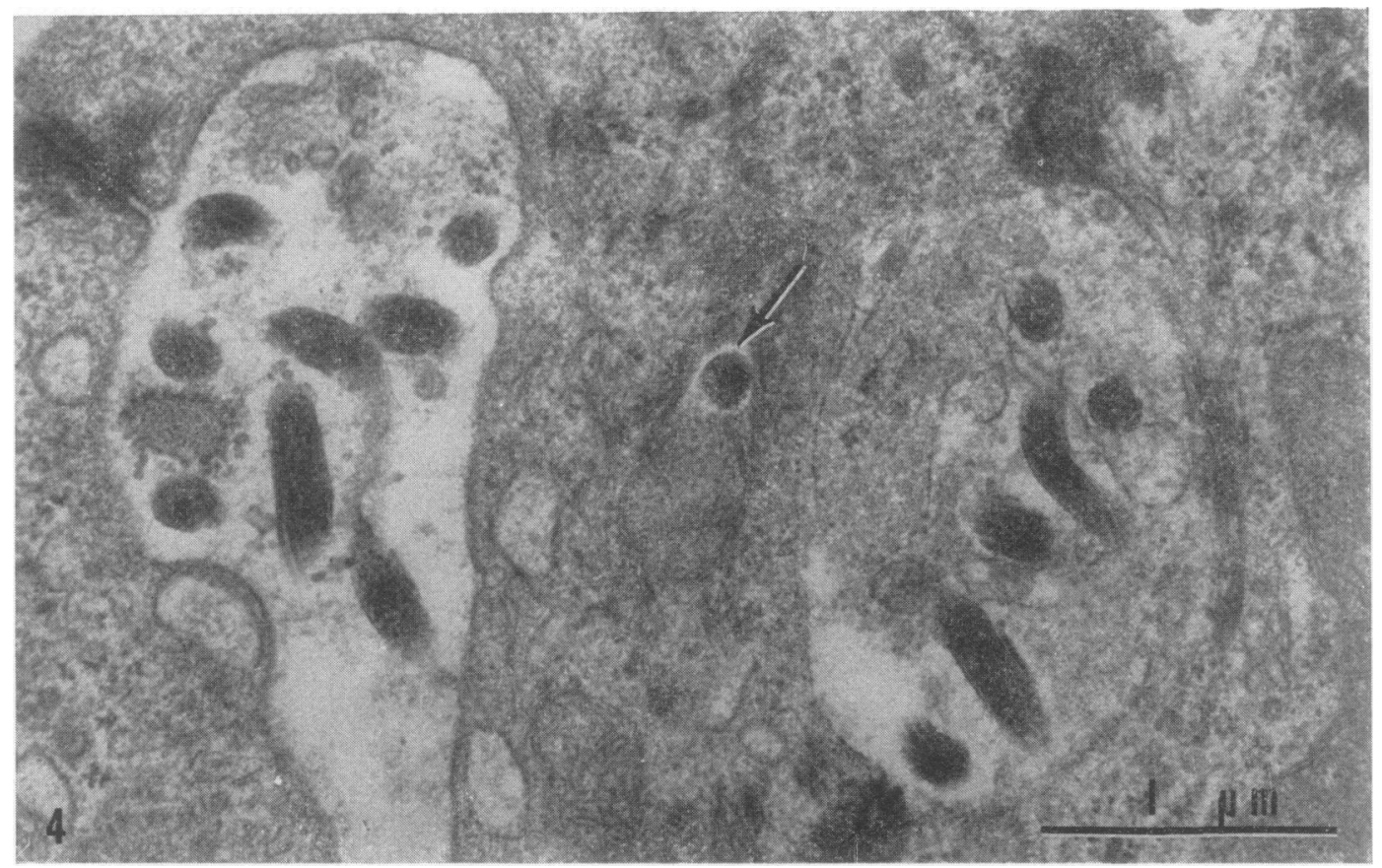

FIG. 4 Parts of three epithelial cells and two intercellular spaces showing various cuts through typical $\mathrm{T}$. pallidum organisms both in the spaces between the cells and in the cytoplasm of the central cell (arrow). The desmosomes and tonofibrillae of the epithelial cells are well demonstrated. The bar represents $1.0 \mu \mathrm{m} . \times 30,000$ 


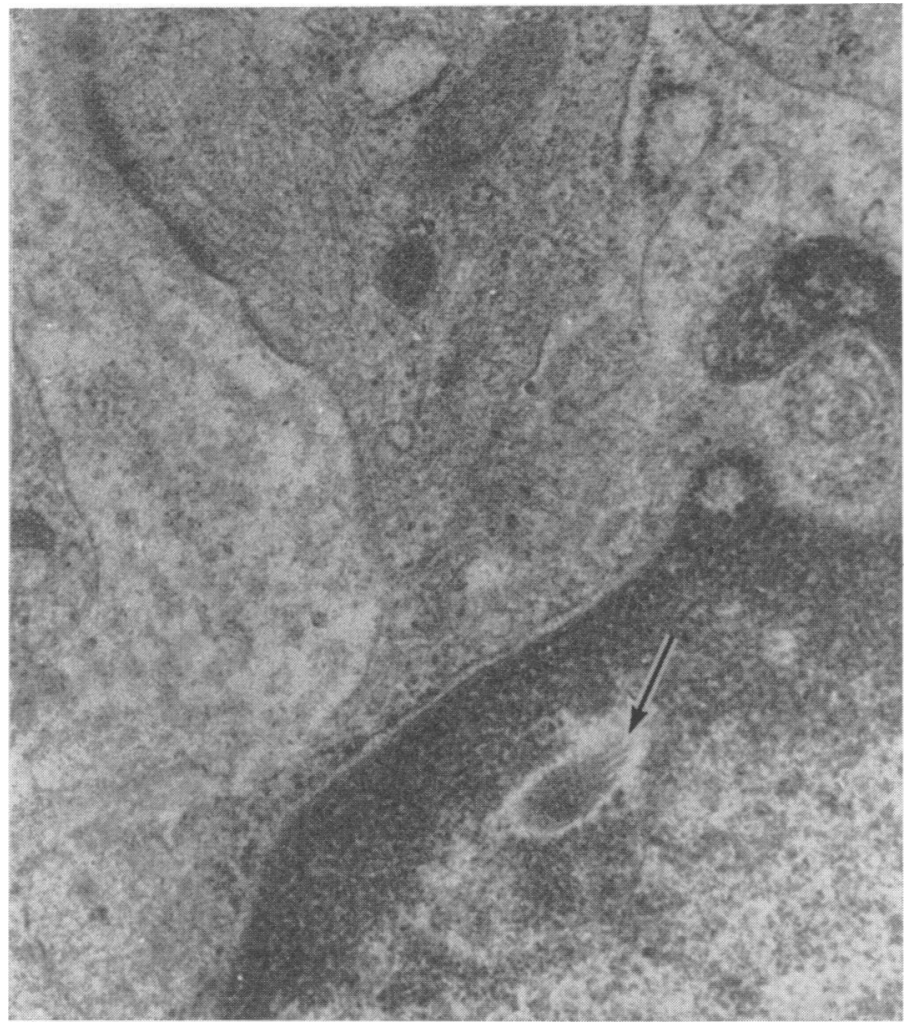

FIG. 5a Part of the nucleus of an epithelial cell from a primary syphilitic lesion in a human female showing an oblique cross-section of a treponeme (arrow). $\times 32,000$

FIG. 5b Detail of treponeme in the nucleus in Fig. 5a. Four axial filaments can be seen (arrow). $\times 70,000$

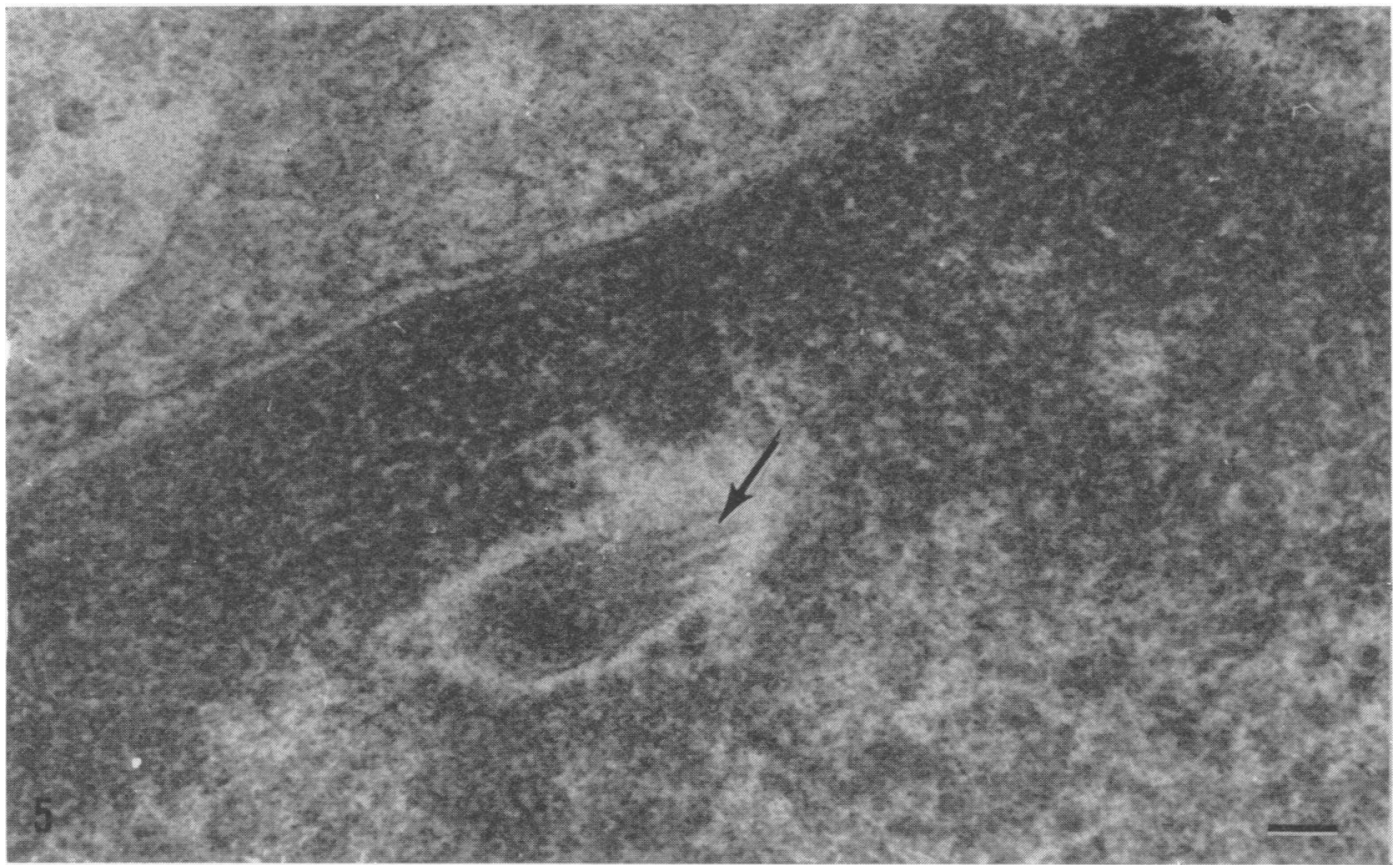


be associated with the phenomenon of latency. It is possible also that difficulties in treating effectively cases of human syphilis could be associated with the observed intracellular location of treponemes which would render them inaccessible to humoural antibodies and to therapeutic substances. These findings indicate that more intensive studies are required of the different manifestations of the disease caused by $T$. pallidum in man.

\section{Summary}

Ultrathin sections of biopsy material from a primary syphilitic lesion in a human female have been examined in the electron microscope. The organisms were found to have the same dimensions (within 4 per cent.) as the pathogenic $T$. pallidum (Nichols) from infected rabbit testes. As with the latter, the organisms in the human lesion were found within the cytoplasm of white cells, fibroblasts, epithelial cells, and endothelial cells. Intranuclear T. pallida were also seen in the nucleoplasm of two epithelial cells.

We thank Mrs. N. Parry for her excellent technical assistance. This work was supported in part by the Albert Soiland Cancer Foundation.

\section{References}

Azar, H. A., Pham, T. D., and Kurban, A. K. (1970) Arch. Path., 90, 143

Drusin, L. M., Rouiller, G. C., and Chapman, G. B(1969) f. Bact., 97, 951

Hasegawa, T. (1969) Brit. f. Derm., 81, 367

LAUDERDAle, V., and Goldman, J. N. (1972) Brit. $\mathcal{f}$ vener. Dis., 48, 87

Millonig, G. (1961) f. appl. Physics, 32, 1637

SYKES, J. A. and MILLER, J. N. (1971) Infect. and Immun. 4, 307

- - (1973) Ibid., 7, 100

Weigand, S. E., Strobel, P. L., and Glassman, L. H. (1972) f. invest. Derm., 58, 186

Treponema pallidum à l'intérieur des cellules d'un chancre primaire chez une femme

SOMMAIRE

Des coupes ultra-fines de matériel de biopsie d'une lésion syphilitique primaire chez une femme ont été examinées au microscope électronique. On trouva que les organismes avaient les mêmes dimensions (à moins de 4 pour cent près) que $T$. pallidum pathogène (Nichols) provenant de testicules de lapins infectés. Comme pour ces derniers, les organismes, dans la lésion humaine, furent trouvés dans le cytoplasme des leucocytes, dans les fibroblastes, les cellules épithéliales et les cellules endothéliales. Des $T$. pallidum intra-nucléaires furent également vus dans le nucléoplasme de deux cellules épithéliales. 